\title{
A clinical study of nutritional status under 5 years of age in correlation with iron deficiency Anemia
}

\author{
Sandeep $\mathbf{B}^{1}$, Harisha $\mathbf{G}^{2}$, Susheela $\mathbf{C}^{3}$ \\ ${ }^{1}$ Dr. Sandeep Bhaskar, Assistant Professor, ${ }^{2}$ Dr. Harisha Gopal, Assistant Professor, ${ }^{3}$ Dr. Susheela C, Professor, all \\ authors are affiliated with Vydehi Institute of Medical Sciences, Whitefield, Bangalore, Karnataka, India.
}

Address for Correspondence: Dr. Harisha Gopal, Assistant Professor, Vydehi Institute of Medical Sciences, Whitefield, Bangalore, India, Email: drharish.g@gmail.com

\begin{abstract}
Introduction: Malnutrition is by far the biggest contributor to child mortality, present in half of all the cases globally. Malnutrition is more common in India than in Sub-Saharan Africa. One in every three malnourished children in the world lives in India. The nutritional status of an individual is often the result of many interrelated factors. Objectives: To identify the nutritional status under 1-5 years of age. To assess the prevalence of iron deficiency anemia in children under 1-5 years of age. Method: The present study is a cross-sectional study conducted in Vydehi Institute of Medical Sciences and Research Centre and Hospital in Bangalore. During the study period about 130 children were enrolled who fulfils the inclusion criteria and those who admitted in Paediatric ward. This study was taken up with the purpose of assessment of nutritional status and the relationship of nutritional status with iron deficiency anemia in children under 5 years of age. Results: According to IAP grading of malnutrition, $12.4 \%$ and $28.5 \%$ children were belonged to grade IV and III, $36.9 \%$ and $22.3 \%$ of children belonged to grade I and II malnutrition. According to this study, malnutrition was more prevalent in female children. The prevalence of severe and moderate, wasting was $40 \%$ and $26.9 \%$, stunting $8.5 \%$ and $15.4 \%$, MUAC $11.5 \%$ and $25.4 \%$. Prevalence of severe and moderate thinness of children according to body mass index was $46.9 \%$ and $36.9 \%$ respectively. The prevalence of iron deficiency anemia in malnourished children was $48.5 \%$ and it was also found that $11.5 \%$ of children were severely anemic and $30.8 \%$ of children were moderately anemic. Conclusion: Malnutrition is a significant problem under 5 years of age which can be reduced with proper education, growth monitoring and good nutrition.
\end{abstract}

Key words: Malnutrition, Wasting, Stunting, Anemia

\section{Introduction}

Malnutrition is a man-made disease. It is a disease of human society. It begins quite commonly in the womb and ends in the grave. Jelliffe listed the ecological factors related to malnutrition as follows: conditioning influences, cultural influences, socioeconomic factors, food production and nutritional status of women of child-bearing age, nutritional status of pregnant woman, nutritional status of lactating women, health and other service [1]. Nutrition is the cornerstone of socio-economic development of the country. Usually referred to as a silent emergency, it has devastating effects on children, society and future human kind [2].

Manuscript received: $10^{\text {th }}$ June 2017

Reviewed: $22^{\text {nd }}$ June 2017

Author Corrected: $30^{\text {th }}$ June 2017

Accepted for Publication: $8^{\text {th }}$ July 2017
Nutritional assessment in the community is essential for accurate planning and implementation of intervention programs to reduce morbidity and mortality associated with under-nutrition. In children, malnutrition is more likely to strike those who lack nutritionally adequate diets, are not protected from frequent illnesses and do not receive adequate care. Factors pertaining to shelter, women's workload and decision making opportunities, traditional beliefs and practices and men's attitude towards child care contribute to malnutrition and eventually to maternal and child deaths [3].

Iron deficiency is the most frequently occurring disorder worldwide and is affecting almost all 
physiological groups; of them pre-school children, pregnant women and lactating mothers are more vulnerable. Iron deficiency in young children can impair their physical growth and cognitive functions such as learning memory and attention process and adversely increase the childhood morbidity and mortality [4].

Nutritional status can be determined with the help of clinical examination of symptoms of nutritional deficiencies, dietary intake and anthropometry. When these methods are used in combination like anthropometry and clinical examination, provide better picture of assessment of nutritional status of children. Anthropometry measurements such as height, weight, mid upper arm circumference, skin fold thickness, head and chest circumference are available indicators of nutritional status. Clinical examination is the simplest and the most practical method of ascertaining nutritional status. There are a number of physical signs, some specific and many non specifics, associated with states of malnutrition [5].

Purpose of the study- The main objective of a "comprehensive" nutritional survey is to obtain precise information on the prevalence and geographic distribution of nutritional problems of a given community, and the identification of individuals or the population groups "at risk" or in greatest need of assistance. In the absence of this information, problems cannot be defined and policies formulated. The purpose of nutritional assessment is to develop a health care program that meets the needs defined by that assessment, including evaluation of the effectiveness of such programs [6].

Preschool children are our future citizens and form an important segment of the Indian human potential and impart population. They contribute to the vital strength to the national economy and development. Only a few studies have been done to study the iron deficiency anemia in malnourished children under 5 years of age. Hence, the present study is undertaken in an attempt to assess iron deficiency anemia in malnourished children in Vydehi Hospital.

Objectives of the study- 1) To identify the nutritional status under 1-5 years of age.

2) To assess the prevalence of iron deficiency anemia in children under 1-5 years of age.

\section{Methods}

This study, a cross sectional study, was done in all children under 1-5 years of age admitted with malnutrition in pediatric ward VIMS \& RC, Bangalore from December 2012 to November 2013 after taking consent from parents.

\section{Exclusion criteria}

- Children more than 5 years of age and below 1 year of age.

- Children with other causes of anemia other than iron deficiency anemia.

- Child with major illness or chronic illness and refractive anemia's.

Sample Size- A minimum sample size of 100 children was required for this study, we have included 130 children admitted during the study period.

\section{Method of collection of data}

- By anthropometric measurements like height, weight, MUAC, head circumference, height/age, weight/age, weight/height will be measured. PEM will be classified according to IAP classification.

- Haematological investigations like $\mathrm{Hb} \%, \mathrm{TC}$, DC, Platelet count, MCV, MCH, MCHC, RBC count, ESR, malaria parasite, stool examination for ova and cysts, peripheral smear was done for cases suspected to have anemia.

Weight- The weighing scale was placed on the flat horizontal surface. The shoes or chapels were removed and child was made to stand on the weighing scale with minimum clothing. The weighing scale was calibrated regularly. Weight should be taken once the weighing scale is kept at zero level.

Height- A vertical wooden stick was used for measurement of height. Measurement was made by the side of the wall. The child with bare foot was made to stand with the heals, buttocks, shoulders and occipital touching the wall and looking straight in Frankfurt plane with hair being flattened completely. The measurement was read by placing the horizontally held wooden board touching the top of the head. Length will be measured by infantometer for children less than 2 years. 
Midarm circumference- Measurement was performed on the left arm, midway between the acromion and olecranon process. The clothing was uncovered over the arm. The measuring tape encircling the arm was held gently without pressing the soft tissues.

Head circumference- While measuring the head circumference, the maximum occipitofrontal circumference was measured by placing the flexible non-stretchable tape firmly over the most prominent region of the occipital and frontal crest. The measurement was taken accurate to the nearest 0.1 $\mathrm{cm}$.

Blood Sample- After taking consent from the parents, Blood samples of the patients included in this study are collected and examined for $\mathrm{Hb} \%, \mathrm{TC}$, DC, RBC, WBC, ESR, Peripheral smear and malarial parasite. $\mathrm{Hb}$ estimation is done by Shalis method, Peripheral smear by Giemsa staining. Stool samples are collected and examined for ova and cyst.

Materials- Materials used were standardized proforma, measuring tape, weighing machine, height measuring scale, stethoscope, infantometer, blood and stool samples.

Statistical Analysis- Data entry and statistical analysis was performed with the help of SPSS version 21. Categorical variables are presented as number and percentage. Chi-square test was used to compare difference in categorical variables.

The $\mathrm{p}$ value $<0.001$ was considered significant and analysis of the data and Microsoft Word and Excel has been used to generate graphs, tables, etc. Frequency, simple proportion and percentage was used for data analysis.

\section{Results}

In the present study, majority (43.1\%) of children belonged to 2 to 3 years age group and $26.9 \%$ belongs to 1 to 2 years. $20 \%$ and $10 \%$ children belongs to $3-4$ and $4-5$ years respectively, out of which $45.4 \%$ children were males and $54.6 \%$ were females. Majority of the children belonged to class II (42.3\%) and class III (33.07\%) according to modified BG Prasad classification.

Table-1: Prevalence of wasting and stunting in children.

\begin{tabular}{|c|c|c|c|c|c|}
\hline Wasting & Number & $\mathbf{\%}$ & Stunting & Number & \% \\
\hline Normal & 16 & 12.3 & Normal & 46 & 35.4 \\
\hline Mild & 27 & 20.8 & Mild & 53 & 40.8 \\
\hline Moderate & 35 & 26.9 & Moderate & 20 & 15.4 \\
\hline Severe & 52 & 40.0 & Severe & 11 & 8.5 \\
\hline Total & $\mathbf{1 3 0}$ & $\mathbf{1 0 0 . 0}$ & Total & $\mathbf{1 3 0}$ & $\mathbf{1 0 0 . 0}$ \\
\hline
\end{tabular}

From our study it was evident that, $11.5 \%$ children was found to be severely malnourished and $40 \%$ of the children were severely wasted and $26.9 \%$ of children were moderately wasted, which is an indicator of shortduration (acute) malnutrition. It was also noted that $8.5 \%$ of children were severely stunted and $15.4 \%$ of children were moderately stunted that is growth retardation which is the indicator of malnutrition of long duration (chronic). Prevalence of severe malnutrition based on BMI was found to be $46.9 \%$.

Table-2: Distribution of children according to grading of Malnutrition - Gender-wise.

\begin{tabular}{|c|c|c|c|c|c|c|}
\hline \multirow{2}{*}{ Gender } & \multicolumn{4}{|c|}{ Grade of malnutrition } & \multirow{2}{*}{ Total } & \multirow{2}{*}{$\%$} \\
\hline & I & II & III & IV & & \\
\hline Male & 13 & 22 & 15 & 9 & 59 & 45.4 \\
\hline Female & 16 & 26 & 22 & 7 & 71 & 54.6 \\
\hline Total & 29 & 48 & 37 & 16 & 130 & 100 \\
\hline
\end{tabular}

Majority of malnourished children belongs to socio economic status class II, III \& IV which is statistically significant $(\mathrm{p}<0.001)$. There was high prevalence of anemia in malnourished children where else $30.8 \%$ was moderately anemic and $11.5 \%$ was severely anemic. 
Table-3: Comparison of malnourished and anemic children with hemoglobin \%

\begin{tabular}{|c|c|c|c|c|c|}
\hline Hb\% & $\begin{array}{c}\text { Grade 1 } \\
\text { malnutrition }\end{array}$ & $\begin{array}{c}\text { Grade 2 } \\
\text { malnutrition }\end{array}$ & $\begin{array}{c}\text { Grade 2 } \\
\text { malnutrition } \\
\text { with IDA }\end{array}$ & $\begin{array}{c}\text { Grade 3 } \\
\text { malnutrition } \\
\text { with IDA }\end{array}$ & $\begin{array}{c}\text { Grade 4 } \\
\text { malnutrition } \\
\text { with IDA }\end{array}$ \\
\hline Normal & 30 & 36 & 0 & 0 & 0 \\
\hline Mild & 0 & 1 & 8 & 0 & 0 \\
\hline Moderate & 0 & 0 & 0 & 39 & 1 \\
\hline Severe & 0 & 0 & 0 & 0 & 15 \\
\hline Total & $\mathbf{3 0}$ & $\mathbf{3 7}$ & $\mathbf{8}$ & $\mathbf{3 9}$ & $\mathbf{1 6}$ \\
\hline
\end{tabular}

In this present study, 15 children were severely anemic and 39 children were moderately anemic, they belongs to III and IV grade of malnutrition which is statistically significant $(\mathrm{p}<0.001)$. It was found that 24 anemic children had worm infestation and other investigations like WBC count, and ESR values are found to be raised in few children indicating that the children had active infection which is due to malnutrition.

Table-4: Distribution of children based on mid arm circumference grading:

\begin{tabular}{|c|c|c|}
\hline $\begin{array}{c}\text { Mid arm circumference } \\
\text { (MUAC) }\end{array}$ & Number & \% \\
\hline Normal & 82 & 63.1 \\
\hline Moderate & 33 & 25.4 \\
\hline Severe & 15 & 11.5 \\
\hline Total & $\mathbf{1 3 0}$ & $\mathbf{1 0 0 . 0}$ \\
\hline
\end{tabular}

From the above table, it was evident that, $11.5 \%$ children was found to be severely malnourished in this study

\section{Discussion}

The present study was conducted with the objective of assessing the nutritional status of children admitted in Vydehi Institute of Medical Sciences and Research Centre Hospital, Bangalore. A total of 130 children were enrolled for the period of 12 months.

According to IAP grading of malnutrition, $12.4 \%$ and $28.5 \%$ children were belonged to grade IV and III, $36.9 \%$ and $22.3 \%$ of children belonged to grade I and II malnutrition. According to this study malnutrition was more prevalent in female children.

Table-5: Comparison of prevalence of malnutrition according to age group, sex and religion with various studies.

\begin{tabular}{|c|c|c|c|c|c|c|c|c|c|c|}
\hline Authors & \multicolumn{2}{|c|}{ Present study } & \multicolumn{2}{|c|}{$\begin{array}{c}\text { Joshi HS et al } \\
{[7]}\end{array}$} & \multicolumn{2}{|c|}{$\begin{array}{c}\text { Imran } M \text { et al } \\
{[8]}\end{array}$} & \multicolumn{2}{|c|}{$\begin{array}{l}\text { Tripathi MS et } \\
\text { al [9] }\end{array}$} & \multicolumn{2}{|c|}{$\begin{array}{c}\text { Harishankar et } \\
\text { al [10] }\end{array}$} \\
\hline 离 & 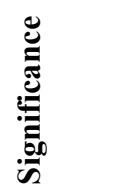 & $\partial^{0}$ & 苋 & $\theta^{\theta}$ & 总 & $\partial^{\theta}$ & 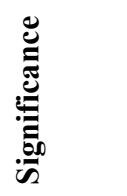 & $\theta^{\circ}$ & 莽 & $\theta^{\theta}$ \\
\hline $\begin{array}{l}\text { Age } \\
\text { Group }\end{array}$ & 2-3 years & $\begin{array}{c}43.1 \\
\%\end{array}$ & $\begin{array}{c}3-6 \\
\text { Years }\end{array}$ & $\begin{array}{c}57.7 \\
\%\end{array}$ & 3-4 years & $\begin{array}{c}59.5 \\
\%\end{array}$ & $\begin{array}{c}3-4 \\
\text { Years }\end{array}$ & $\begin{array}{l}33 \\
\%\end{array}$ & $\begin{array}{c}2-3 \\
\text { Years }\end{array}$ & $\begin{array}{c}78.30 \\
\%\end{array}$ \\
\hline Sex & Females & $\begin{array}{c}54.6 \\
\%\end{array}$ & Females & $\begin{array}{c}61.2 \\
\%\end{array}$ & Males & $\begin{array}{c}46.3 \\
\%\end{array}$ & Males & $\begin{array}{l}61 \\
\%\end{array}$ & Males & $58 \%$ \\
\hline Religion & Hindu & $\begin{array}{c}76.9 \\
\%\end{array}$ & - & - & Hindu & $\begin{array}{c}81.6 \\
\%\end{array}$ & - & - & Hindu & $\begin{array}{c}97.9 \\
\%\end{array}$ \\
\hline
\end{tabular}


According to Joshi HS, PEM in under 6 years children was observed to be $49.44 \%$, however it was found to be significantly higher $(64.87 \%)$ in the age group of 3-6 years as compare to other age group and more in females. The proportion of grade I, II, III and IV of under nutrition observed was $45.49 \%, 38.30 \%, 14.86$ and $1.35 \%$ respectively [7].

According to Imran $\mathrm{M}$ et al [8], prevalence of malnutrition was more in 3-4 years age group, more in male children and majority of them were Hindus and also it was found that $116(47.3 \%)$ of the children are underweight out of them $87(35.5 \%)$ and $29(11.8 \%)$ of children are in grade I and grade II PEM respectively. 66 (27\%) children had stunting (low height for age) out of them 54 (22\%) of children had mild stunting and 12(4.9\%) of children had severe stunting [8].

A study conducted by Harishankar et al [10], the prevalence of malnutrition was found more in 2-3 years of age group, more in males and majority of them were Hindus.

The prevalence of iron deficiency anemia in malnourished children was $48.5 \%$ and it was also found that $11.5 \%$ of children were severely anemic and $30.8 \%$ of children were moderately anemic. In that most of the children belonged to grade III and IV malnutrition and very few children belonged grade II malnutrition.

Table-6: Comparison of stunting and wasting with various studies with prevalence of anemia.

\begin{tabular}{|c|c|c|c|c|}
\hline Authors & Stunting & Wasting & Authors & $\begin{array}{c}\text { Prevalence of anemia } \\
\text { (\%) }\end{array}$ \\
\hline Present study & $23.9 \%$ & $66.9 \%$ & Present study & $48.5 \%$ \\
\hline Alzain Bassam [13] & $34 \%$ & $20.3 \%$ & Jood S et al [11] & $8.89 \%$ \\
\hline Singh MB [14] & $53 \%$ & $28 \%$ & Sudhagandhi B et al[12] & $75.2 \%$ \\
\hline Awasthi et al [17] & $87.6 \%$ & $4.3 \%$ & Alzain Bassam [13] & $65.3 \%$ \\
\hline Bains K et al [18] & $70.1 \%$ & $62.7 \%$ & Singh BM et al [14] & $30.5 \%$ \\
\hline Muaz SSA [19] & $80.3 \%$ & $42.3 \%$ & Vinod M et al [15] & 78.71 \\
\hline Biswas S et al [20] & $48.2 \%$ & $10.6 \%$ & George KA et al [16] & $53.3 \%$ \\
\hline
\end{tabular}

In the study conducted by Jood S et al, $8.89 \%$ of preschool children had pale conjunctiva. According to NFHS-3 prevalence of anemia in India was $69.5 \%$ and in Karnataka was $70.4 \%$ [11].

According to a study conducted by Sudhagandhi B et al, the prevalence of anemia was reported $75.2 \%$. The percentage of anemic children among male and female was deducted $79.1 \%$ and $71.7 \%$ respectively. BMI and socio-economic factor were important determinants of anemia [12].

According to Alzain B the prevalence of anemia in preschool children was $65.3 \%$. Among them $34 \%$ were stunted, $20.3 \%$ were wasted and $45 \%$ children were underweight [13].

A study conducted by Singh BM et al, the prevalence of malnutrition was $44.4 \%$ and the prevalence of anemia was $30.5 \%$ in Rajasthan [14].According to Vinod $\mathrm{N}$ et al, the prevalence of anemia was $78.71 \%$ and $52.23 \%$ was due to malnutrition [16].

Anthropometric nutritional status was assessed by WHO criterion (SD classification) and also NCHS standard using weight for age, height for age, weight for height indices and MUAC. The prevalence of severe and moderate, wasting was $40 \%$ and $26.9 \%$, stunting $8.5 \%$ and $15.4 \%$, MUAC $11.5 \%$ and $25.4 \%$, prevalence of severe and moderate thinness of children according to Body mass index was $46.9 \%$ and $36.9 \%$ respectively.

According to the study conducted by Awasthi S et al, $67.3 \%$ of preschool children were underweight and $87.6 \%$ were stunted [17]. The study by Bains $\mathrm{K}$ and Brar JK reported $21 \%$ of moderate and $15 \%$ of severe stunting in children [18]. 
In another study conducted by Biswas $\mathrm{S}$ et al revealed that among children, $48.20 \%, 10.60 \%$, and $48.30 \%$ were having stunting, wasting and underweight respectively [20].

In the present study, $21.5 \%$ of class IV, $33.1 \%$ of class III and $42.3 \%$ of class II were malnourished children, while only $3.07 \%$ of class I were malnourished. Hence, it was observed that malnutrition was seen more commonly seen in the lower socio-economic status.

Table-7: Comparison of nutritional status of children according to SES with various studies.

\begin{tabular}{|c|c|c|c|c|c|c|}
\hline \multirow{2}{*}{$\begin{array}{c}\text { Nutritional status of } \\
\text { children according to SES }\end{array}$} & \multicolumn{2}{|c|}{ Present study } & \multicolumn{2}{c|}{ Imran et al [8] } & \multicolumn{2}{c|}{ Luthra M et al [21] } \\
\cline { 2 - 7 } & No. & $\%$ & No. & \% & No. & \% \\
\hline Class I & 4 & $3.07 \%$ & 0 & 0 & 12 & $5.95 \%$ \\
\hline Class II & 55 & $42 \%$ & 10 & $8.62 \%$ & 24 & $33.8 \%$ \\
\hline Class III & 43 & $33 \%$ & 76 & $65 \%$ & 31 & $36.9 \%$ \\
\hline Class IV & 28 & $21 \%$ & 30 & $25.8 \%$ & 24 & $28.5 \%$ \\
\hline Class V & 0 & 0 & 0 & 0 & 0 & 0 \\
\hline
\end{tabular}

In the study conducted by Harishankar et al, $69.23 \%, 24.79 \%$ and $5.98 \%$ of malnourished children belonged V, III and I respectively [10].

A study conducted by Luthra $\mathrm{M}$ et al, the results showed $41.2 \%$ were severely malnourished, $38.3 \%$ were males and $44.9 \%$ were female children, most of them belong to 3-5 years age group and they were from low socio economic status. Among them $66.7 \%$ and $40.2 \%$ belongs to SES II and III respectively [21].

\section{Conclusion}

- The prevalence of malnutrition is more common in children under 5 years of age from low socioeconomic status. The incidence is more in Female children, since the girl child is most neglected in the society.

- The most commonest micronutrient deficiency in malnourished children is iron deficiency which leads to Nutritional anemia which is aggravated due to parasitic infestation which in turn due to low socio economic status and unhygienic living condition.

- Anemic infants are susceptible to delayed cognitive development and at high risk of infectious disease in childhood age. The improvement of nutritional status would reduce the prevalence of anemia and protects infants from its complications. Hence, the child mortality and morbidity can be reduced drastically.

Funding: Nil, Conflict of interest: None initiated, Perission from IRB: Yes

\section{References}

1. Jelliffe DB. The assessment of nutritional status of the community. WHO Monograph;1966. Report No:53.
2. Hassam. SL, Mahmood UR, et al. Assessment of nutritional status of 1-5 year old children in an urban council of Abbottabad. J. Ayub Med Coll Abbottabad 2010;22(3):124-127.

3.Singh R, Bhatnagar M, Mathur B, Singh H, \& Kr Y. Comparative study of nutritional status of primary school children in urban area of Jhansi. Indian J Commun Health 2009-2010; 21(1,2):56-60.

4. Arlappa N, Balakrishna N, Laxmaiah A, Brahmam GNV. Prevalence of anemia among rural preschool children of Maharashtra, India. Indian J Commun Health 2012;24(1):4-8.

5. Park K. Park's Text book of Preventive and Social Medicine. $21^{\text {st }}$ ed. Jabalpur: M/s. Banarsidas Bhanot Publishers; 2011.

6. Tetzel B. S. Oxford Text book of Public Health . Oxford.Oxford University Press; 1985.

7. Joshi HS, Joshi MC, Arun Singh et al. Determinants of Protein Energy Malnutrition (PEM) in 0-6 Years Children in Rural Community of Bareilly. Indian J Prev. Soc. Med. 2011;42(2): 154-158. 
8. Imran M, Nawazudin K et al., A Study on Prevalence and Determinants of Protein Energy Malnutrition among 2-6 Year Anganwadi children in rural Bangalore. International Journal of Basic and Applied Medical Sciences. 2012; 2 (3): 109-115.

9. Tripathi MS, Sharma V. Assessment of nutritional status of pre-schoolers in Slum areas of Udaipur city. Indian J Community MedPublic Health. 2015 May;2(2):124-126.

10. Harishankar, Dwivedi S, Darbal SB, Walia DK. Nutritional status of children under 6 years of age. Indian J Prev. Soc. Med. 2004; 35 (3 \& 4): 156-62.

11. Jood S, Bishnoi S, Sehgal S, Nutritional status of rural pre-school children of Haryana State. Indian J Pediatr 2000;67(3):189-196.

12. Sudhagandhi B, Prema A et al., Anemia in Toddlers Of Kattankulathur, Kancheepuram District (TN), India. Indian J Pharma 2012; 3: 687691.

13. Alzain Bassam.. Anemia and Nutritional Status of Preschool Children in North Gaza, Palestine. International Journal of Scientific \& Technology Research .2012 Dec;1(11):86-91.

14. Singh BM, Lakshminarayana $J$ et al. Childhood Illnesses and Malnutrition in under Five Children in Drought Area of Western Rajasthan. India. J Commun Dis. 2006;38(1):88-96.
15. Vinod N, Umesh $\mathrm{S}$ et al. Morbidity Profile in under Five Children in Urban Slum Area of Nagpur. National J Commun Med 2012 Jul-Sept; 3(3): 442-446.

16. George KA, Suresh Kumar N, John J Lal, Sreedevi R. Anemia and nutritional status of preschool children in Kerala. Indian J Pediatr 2000 Aug; 67(8): 575-78.

17. Awasthi S, Das R, Verma T, Vir S. Anemia and undernutrition among preschool children in Uttar Pradesh, India. Indian Pediatr. 2003 Oct;40(10): 985-90.

18. Bains K, Brar JK. Assessment of nutritional status of 1-5 year old children belonging to farm families of Punjab, Indian J Nutr Diet 2009;46: 345-50.

19. Muaz SSA, Hasan MR, Shamim SA. Nutritional status of 1-5 years children of the tea workers in Sylhet division. Bangladesh J Child Health 2010; Vol 34 (1): 11-16.

20. Biswas S, Bose K, Mukhopadhyay A, Bhadra M. Prevalence of undernutrition among pre-school children of Chapra, Nadia District, West Bengal, India, measured by composite index of anthropometric failure (CIAF).Anthropol Anz.2009 Sep;67 (3): 269-79.

21. Luthra M, Paevan UC. Epidemiological correlates of under nutrition in o-5 year old children in rural field areas of SGRRIM \& HS, Dehradun. Indian J Prev. Soc. Med. 2010; 41 (1 \& 2):8-10.

\section{How to cite this article?}

Sandeep B, Harisha G, Susheela C. A clinical study of nutritional status under 5 years of age in correlation with iron deficiency Anemia. J PediatrRes.2017;4(07):481-487.doi:10.17511/ijpr.2017.i07.08. 